\title{
African Immigrants in Argentina Post-Slavery: An Old-New Odyssey
}

\author{
Alain Lawo-Sukam • Texas A\&M University
}

\begin{abstract}
In this interdisciplinary article, I address the less known migration of Africans in South America, especially in Argentina. This is significant because studies on African migrations have focused mainly on European and North American routes (north-south), living aside south-south paths. The complex experience of the first African immigrants in Argentina relates to a certain extent and also contrasts with the recent migrations of the twenty-first century. Because of (post) colonial history, collective/personal experience and stories, African immigrants are finding new homes in Argentina. However, recent changes in immigration policies relaxed under previous governments could jeopardize this el dorado. This article also intends to re-frame studies on African immigration in Argentina that have concentrated their attention on Sub-Saharans and left aside North African as well as South African (Boers) experiences. I argue that to talk about African diaspora (hi)story in Argentina is to embrace Africanness in its totality and complexity, as well as embracing Pan-Africanism beyond Pan-Negroism. This study takes into consideration the framing questions on migration raised by Hasia Diner, Kim Butler, Caroline Brettell, and James Hollifield which includes the reasons for and conditions of the dispersal. The article is also based on eclectic sources combining personal experience, interviews, archival sources, history, and critical analysis. ${ }^{1}$
\end{abstract}

A rgentina is one of the whitest countries in Latin America due to the successful implementation of the blanqueamiento (whitening) policies that promoted European immigration after independence and throughout the twentieth century. Despite the effort made by other countries such as Mexico, Colombia, and Brazil to develop the ideologies of mestizaje (miscegenation) as a nationalistic move to respond to the questions of race and nation, Argentina's political and intellectual elites decided to construct national identities that were exclusively Eurocentric. As a consequence of the whitening ideologies, Argentinians of African and indigenous descent were progressively erased from national consciousness. Blackness in general ceased to be an official marker of demography and national identity. ${ }^{2}$

In the face of widespread denial or ignorance about the survival of Argentinian African heritage, scholars such as George Reid Andrews, Dina Picotti, Marvin A. Lewis, Alejandro Solomianski, Alejandro Frigerio, Marta Maffia, Eva Lamborghini, Alex Burucki, and Erika Edwards, among others, have examined and documented for more than thirty years the life and experience of Afro-Argentinian communit(ies) in the nineteenth, twentieth, and twenty -first centuries. ${ }^{3}$ The (hi)story of Afro-Argentinians is also intertwined with African diasporic migrants from Uruguay, Brazil, Peru, Ecuador, and Cuba. Those migrants, especially from Uruguay and Brazil, have spearheaded the fight against racism and the invisibility of Blackness in the national discourse since the second half of the 1980s. They were also responsible for the recognition of the African heritage and contribution to Argentine history and culture (Frigerio 2008, Andrews 2004 and 2010, Lawo-Sukam 2015). The presence of Afro-Latin Americans in Argentina has not only enhanced black Argentinian militancy, but has also slowly reinvigorated the physical and cultural Africanization of the country through cultural activism (Frigerio and Lamborghini 2011, Lawo-Sukam 2015). ${ }^{4}$ The efforts made by Afro-Latin Americans to reconnect the society with its African past have not only contributed to the resurgence of Afro-Argentine identity, but have also opened the door to a 
critical rethinking of African migration in Argentina after the abolition of slavery established by the constitution in 1853 .

Walking the neighborhoods of Abasto and Flores in Buenos Aires a few years back (2013 and 2016), I was astonished to see Africans selling jewelry, belts, and watches. Those street vendors reminded me of other Africans I met on the streets of Madrid selling similar merchandises. My curiosity led me to meet three vendors who reluctantly spoke to me, since they were busy selling their goods. Recognizing their struggle with the Spanish language, I decided to converse in English, although it was in vain. I then switched to French which proved to be the key for openness and further interactions. From our conversations, I discovered that they were Senegalese and Malians who have lived in Buenos Aires for half a decade. They also reported on the presence of migrants from Nigeria, Ivory Coast, Congo, Cameroon, and other Sub-Saharan African countries. I was puzzled by the shift in migration pattern for those Africans whose typical travel destinations are Europe, North America, Asia, or Australia. During my journey, I also met Moroccans and South Africans who chose to migrate to Argentina mostly for business and academic reasons. The encounter with African migrants gave me the opportunity to think about new spaces of African migration. ${ }^{5}$

The present analysis follows the trend of studies on Blackness and African identit(ies) in Argentina. Specifically, it examines and analyzes the demography and (hi)story(ies) of African migrants in Argentina post-slavery, as well as immigration policies. Contrary to the majority of studies that focus particularly on segments of Sub-Saharan African migrants (Marta Maffia, Paola, Monkevicius, Miriam Gómes, Bernarda Zubrzycki, Boubacar Traore, and others), this work uses a holistic and inclusive approach that covers African migrant communities in general, adding the "forgotten" layers of the Maghreb and Southern Africa. I argue that the discourse of Africanity and African diaspora in Argentina has to go beyond the sole experience of Sub-Saharan to encompass the ethnic-racial plurality and complexity of the continent. The history of African migration in Río de la Plata (post-slavery) is not only the stories of Sub-Saharan (or Black) Africans, but of North Africans and South African Boers as well. I also argue that African immigrants ended up in Argentina for different reasons, which include colonial /postcolonial history and experiences, the changes in migration patterns influenced by major world events in Europe and America, the flexibility of immigration laws in Argentina under Néstor and Cristina Kirchner's presidency, and by unfortunate circumstances that prevented them from reaching North America. It is impossible to understand African migration to Argentina without considering those parameters.

On the other hand, the complex experience of African immigrants from Morocco, Cape Verde, and South Africa in the second half of the nineteenth and beginning of the twentieth centuries is parallel to, and to a certain extent contrasts with, the recent migration of other African communities from Senegal, Cameroon, Angola, Ivory Coast, and Nigeria, among others, who arrived mainly at the end of the twentieth and beginning of the twenty-first centuries. Once in Argentina, Africans forged "imagined" communities that catered to the needs of their constituents. Nevertheless, this ethno-racial centrism might also endanger the very basic notion of Pan-Africanism in its continental and global sense. Furthermore, the denial of African root or Afro-descendant identity is one of the factors that contribute to the erosion of a collective Pan-African identity.

I want to clarify and emphasize that this study focuses on the history of Africans who arrived in Argentina after the abolition of slavery, and not on the experiences of slaves during the colonial period. It elaborates a unique history of African migrants through the same census data which historically privileged and highlighted European immigration. This study also takes into consideration the following questions on migration raised by Hasia Diner: "'Who moves?', 'Why do some human beings get up and shift residence?', 'How do they get there?', and those raised by Caroline Brettell and James Hollifield: "How do those who move experience departure, migration, and settlements?" (Diner 33, Brettell and Hollifield 4). These questions guide social scientists and humanists in their analysis of population movements, and are aligned with the quest for the reasons and conditions of population dispersal as mentioned by scholars such as Kim Butler (195). Why Africans leave their homeland, how they leave, arrive, and survive in the hostland are important factors for a better understanding of African migrations. The reasons of the dispersal are personal or collective, voluntary or involuntary. ${ }^{6}$ As an interdisciplinary endeavor, this paper is based on eclectic sources combining personal experience, historical methods that rely on archival sources (mostly census data), newspapers, and interviews made in Buenos Aires during my trips in 2013 (May-June) and 2016 (September). Archival work was important to access the census data from 1869 to 2010 in order to analyze the history of African migration in Argentina. The cultural immersion in the African immigrant communities gave me a vantage point to observe and interact with members of the dispersed population. Those interactions, often through interviews, provided information helpful to better understand the experience of immigrants. Some of the data used in this study were collected through interviews done by journalists and published in newspapers, among other media outlets. 


\section{THE PROBLEMATIC USE OF DEMOGRAPHY (CENSUS)}

The few scholarly studies on African migration in Argentina have primarily focused their attention on recent migrations of the late twentieth and the beginning of the twenty-first centuries. Even though the vast majority of African migrants came to Argentina in the twenty- first century, it is important to state that the first waves arrived at the end of the nineteenth century and the beginning of the twentieth. Marta Maffia suggested that Cape Verdeans were the first Sub-Saharan Africans to migrate to Argentina ("La migración subsahariana hacia Argentina" 67). Furthermore, Pedro Marcelino and Marcela Cerrutti revealed not only the presence of Cape Verdeans but also South Africans (123). While researching in the archives, principally the National Census conducted by the Comisión Directiva del Censo Nacional (CDCN) on May 10th, 1895 under the administration of President Saenz Peña, I came across other African nationalities from Morocco, Egypt, and Algeria. Thus, not only Sub-Saharan Africans arrived to Argentina at the end of the nineteenth century, but also North Africans.

The statistic about the exact number of African immigrants in Argentina has been shrouded in mystery since the nineteenth century, when the authorities vigorously implemented policies to whiten the country. In 1857, Argentina started to collect statistical data on immigrants. The first national census of the population, conducted in September 1869, registered 211, 993 foreigners, among which numbered 43,663 Americans, 167,158 Europeans, 1,172 Asians, and others (De La Fuente, Primer Censo XXXI). 7 The census didn't mention immigrants from Africa. We don't know if Africans were implicitly among those considered as "others."

Twenty-six years later, the second national census of 1895 was conducted by the Commission CDCN (Comisión Directiva del Censo Nacional). It included African immigrants as "foreigners". The CDCN classified foreigners in several categories, among which were raza (race), sexo (sex) and nacionalidad (nationality). What the CDCN considers raza (race) in the census charts is more related to national/ geographic identifiers, not traditional racial categories such as White, Negro, Mestizo, Mulatto, and etc. Race is a social construct and its definition has changed overtime. For the purpose of this study, I use the racial terminologies of the census Commission of 1895 .

In terms of race and sex, the "raza Africana" (African race) totaled 454 members, with 290 males and 164 females (De La Fuente, Segundo Censo XLV). ${ }^{8}$ The 454 members of the African race are also categorized by nationalities. According to the census chart, Moroccans numbered 75, Egyptians 39, Algerians 35, and "Africanos sin especificación” 305 (XLIV \& CLXVI). Using the census charts of 1895, I suggest that the Commission provided some information that officially confirm the presence of African immigrants in Argentina in the second half of the nineteenth century. In addition to the African race", the census charts also provided data on other components of Argentinian "foreign" populations dominated by the Latin race, Germanics, and Anglo-Saxons, among others: "La raza latina forma, pues, la inmensa mayoría de la población, con el 975 por mil sobre su total; pero las germánicas, anglo-sajonas, escandinavas con el 25 restante, contribuyen al mejoramiento de ella..." (XLV).

If, as George Reid argued, statistical data on the racial composition of Latin American countries are scarce, and countries such as Uruguay and Argentina over the course of the nineteenth century eliminated race from their census forms, the Argentinian census charts of 1895 show otherwise (205). Not all "races" were eliminated from the census. Some racial categories such as "Latina", "Germánica", "Anglosajona", "Esclava," "Escandinava," "Asiática," and "Africana” appeared on the tally. Some of these national/geographical markers used by the Commission as racial categories are part of a macro-racial identification. For example, European immigrants belong to the "raza blanca": "Habiendo llegado al país desde 1857 dos millones y medio de europeos, ..., se comprende que casi la totalidad de la población pertenece a la raza blanca" (De La Fuente, Segundo Censo XLVI). Even though the members of the Commission use expressions such as "raza blanca" and "raza negra", they mainly construct their racial categories around national/ethno-geographical markers.

If African immigrants are represented on the census charts, it is not the case for Afro-Argentinians who have been part of the country's demography for centuries. Commenting on the concept of race, the Commission reported that there were 8,000 Blacks and Mulattos registered in the city of Buenos Aires in 1887, among which 3,300 were males and 4,700 were females (XLVIII). Even with this data in its possession, the Commission didn't put it on the census charts. The Commission justified the decision to exclude the "raza negra" from the 1895 census based on their rapid decrease and their subsequent fusion/absorption into the White race. (XLVIII). The Black race could not expand and remain pure enough to survive over time (XLVIII). ${ }^{9}$ It suffices to suggest that the desire to whiten the nation facilitated the (quick) disappearance of AfroArgentinians from the 1895 census charts. There was a deliberate political attempt by the state to praise, favor, and facilitate mass immigration of Europeans who were considered superior and necessary to the whitening and modernization of the country. According to the Comisión Directiva del Censo Nacional (CDCN) of 1895 ,

Habiendo llegado al país desde 1857 dos millones y medio de europeos,..., se comprende que casi la totalidad de la población pertenece a la raza blanca...no tardará en quedar su población unificada por completo formando una nueva y hermosa raza blanca producto del contacto 
de todas las naciones europeas fecundadas en el suelo americano. (XLVI-XLVIII)

Even though the Afro-Argentinian population was decreasing as the Commission stated, it couldn't have been less than the African immigrant population of 454 reported in the 1895 census chart. The fact that the Commission (CDCN) omitted the native black population from the census charts (using the pretext that they were disappearing fast), but mentioned explicitly the presence of Africans from the Maghreb, shows the preference of the Commission to move away from Blackness. Coming from "whitened" North African areas at that time, Moroccans, Algerians, and Egyptians were more desirable than native Afro-Argentinians. Those North Africans could have easily passed for White or identified themselves as such in a country poised to whiten itself. ${ }^{10}$

Contrary to European immigrants who were ethno-racially classified as Germanic, Anglo-Saxon, Slav, Scandinavian, and "Latinos de otros idiomas", the census grouped Africans in a single racial unit: "Africano" (XLV). ${ }^{11}$ The ethno-racial complexity of Africa was not taken into consideration. The racial generalization of Africans can be interpreted as the politics of marginalization that symbolically depreciates the ethno-racial plurality of Africa, but gives recognition and appreciation to diverse European identities. The myth of Africa as an ethno-racial singularity could also be linked to the nineteenth- century Eurocentric conceptualization of the continent as a monolithic entity. As Cemil Aydin put it:

Only in the 19th century, together with the development of a continental scheme of world geography, did Africa begin to be conceived of as a continent with distinct characteristics, especially with a Black race, that separate it from Europe and Asia. Thus, despite the cultural and ethnic differences between the north and Sub-Saharan Africa, a fact that was especially emphasized by medieval Muslim geographers, a metageographic myth of the African continent became universally accepted during the globalization of Eurocentric knowledge categories. (15-16)

If the Commission collapsed African immigrants (495 people) into one racial category ("Africano"), it was not the same for nationalities. The simplified metaracial myth of Africa didn't extend to nationalities since the census made official allusion of Moroccans, Egyptians, and Algerians. In this context, the border between race and nationality is more explicit. The concept of "Africano" as a racial category in the census was not automatically translated as "Africano" in terms of nationality, except for those African immigrants whose nationalities could not be established. They were classified as "Africanos sin especificación". These
African foreigners without nationality were 305 people (De La Fuente, Segundo Censo XLIV, XLV). It is possible that they arrived straight from Africa or through a third country. It is unclear why the Commission could not specify the nationalities of these immigrants. I suggest that the lack of nationality reference could derive from the political (de)construction of Africa by European imperialist nations. In the second half of the nineteenth century, most territories in Africa were not consolidated as a nation. They were either no man's land, kingdoms, indigenous lands, colonized, disputed, or divided among powerful European nations after the Berlin Conference of 1884-1885.

The third national census of June 1914 revealed the total number of African immigrants to be 1,838 , among which there were 802 Moroccans, 258 South Africans, 130 Egyptians, 125 Algerians, and 523 unspecified Africans identified as "Africanos no deternimados" (397). From that data, 103 immigrants (50 Moroccans, 30 South Africans, 7 Egyptians, and 16 others) were "naturalizados" or naturalized citizens (Martínez 417). ${ }^{12}$ Contrary to the national census of 1895 that mentioned specifically the presence of Algerians, Moroccans, and Egyptians, this third census included South Africans as a new category of African immigrants.

It is important to state that despite the presence of Cape Verdeans in Argentina in the late nineteenth century, they were mentioned neither in the census of 1895 nor 1914. It is hard to tell if they were included in the category of Africans without specification since they were coming from the African continent. It is also possible that they were counted as Portuguese because they migrated with Portuguese nationality (Monkevicius and Maffia, "Memoria y límites étnicos" 119).

The fourth national census of May 1947 did not provide the number of African immigrants. According to the Dirección Nacional del Servicio Estadístico that conducted the census of 1947, there were 2,435,927 foreigners living in Argentina, among which 87,272 were primarily from Africa and Asia (LXIV). There was no clarity on the number and nationalities of African immigrants. The fifth national census of 1960 reported a total of 2,827 Africans, without detailing their nationalities (Dirección Nacional de Estadística y Censos 14). ${ }^{13}$ The sixth, seventh, and eighth censuses of 1970, 1980, and 1991 respectively do not mention the number of African immigrants. The ninth national census of November 2001 reported 1,883 Africans ("INDEC")..$^{14}$ The majority of those migrants were born in Egypt (328), Morocco (287), and South Africa (213)..$^{15}$

The tenth and most recent national census was conducted on October 27, 2010. This census considered a category for Afro-descendants. According to INDEC (2012), the census of 2010 reported that 149,493 people self-recognized as Afro-descendant; 76,064 were males and 73,429 were females. 92\% $(137,533)$ of Afro-descendants were born 
in Argentina and 8\% $(11,960)$ were born elsewhere. From the $8 \%$ of Afro-descendants born abroad, $84.9 \%$ were born on the American continent and 8.7\% in Africa (296299). If we consider the INDEC statistics, around 1,041 Afro-descendants were born in Africa before migrating to Argentina. This number of African born immigrants seems to contrast with the overall population of those born in Africa, which totaled 2,738 people (96). Since those who identified as Afro-descendant and born in Africa totaled 1041, the remaining population of 1697 did not identify as Afro-descendant or as people of African origin. This portion of the population from Africa that doesn't auto-identify as Afro-descendant problematizes the very notion of "Afro-descendiente".

Why is that African immigrants born in Argentina do not identify as Afro-descendents since, generally speaking, the expression refers to a person of African descent or origin? An explanation could be found in the approach or the terminology. Afro-descendant is often linked with black Africa and/or descendant of slaves, for example, in the Americas. In that perspective ("Afro-negroid”), non-black ethnic-racial migrants born in Africa might not necessarily identify themselves as Afro-descendant but African. This was the case of one (Indian) South African who told me that he is African and not Afro-descendant, since he associated Afro-descendant only with Blackness and could not recognize himself as such. Furthermore, few individuals from the Maghreb preferred to be called Arab or Middle Eastern rather than African, running away from the negative stereotypes associated with the African continent. Moreover, not all African immigrants would consider themselves Afrodescendant if they could pass for White (the census relies mostly on self-recognition), and benefit from white privilege. In a country where blanqueamiento is favored and encouraged, it is possible for some African descendants to hide their Africanness if they can.

This misrepresentation of the continent might have affected the view of the 1,697 people born in Africa who did not identify themselves as African descendants. This exclusivist idea leads to a reductionist mentality that is not only prejudicial to a proper conceptualization of African diasporic identity, but also jeopardizes the very basic notion of Pan-Africanism defined by Mario Azevedo as "the multifaceted movement for transnational solidarity among African people with the purpose of liberating and unifying Africa and peoples of African descent" (173). The ideal of concretizing the bond between Africa and its diaspora and strengthening the relation among Africans everywhere in the world would be more difficult and problematic if there is not an inclusive approach to the concept of Pan-Africanism in its unifying meaning. In this regard, the goal of unifying Africa and its diaspora is achieved by incorporating all the diverse geographical and ethnic-racial components of the continent. African descendant people from the Maghreb and Sub-Saharan Africa partake in the discourse of PanAfricanism and the building of better/stronger African/Black communities around the world.

If the national censuses give us a historical statistical idea about the number of African immigrants in Argentina, data from the Comisión Nacional de Refugiados (CONARE) and the Dirección Nacional de Migraciones (DNM) add more details. From 1991 to 2010, the CONARE listed 430 African refugees from 26 countries. ${ }^{16}$ Census on immigrants and ethnicity is always an arduous task, hard to establish and very controversial. It is difficult to know how many African immigrants were not registered because of the lack of a fixed home address, or did not want to be registered for being undocumented or for personal reasons. Furthermore, not all African immigrants view themselves as African descendant and may pass for White in the census. This form of de-Africanization of African people also applied to the first generation of Cape Verdean migrants in Argentina who saw themselves more Portuguese than Africans. As controversial and contentious as these statistics can be, they highlight at least the importance of the African immigrant population. The next national census of 2020 will give more input and update on the migration of Africans to Argentina.

\section{THE (HI)STOR(IES), POLICIES, AND CHALLENGES OF MIGRATION}

According to the second national census of 1895, Moroccans, Egyptians, and Algerians are considered early African immigrants. Nevertheless, the presence of Cape Verdeans who were not formally included on the census also shows that they were among those early African immigrants. As we can see later, their disassociation with Africanness could have been a reason for this exclusion. In the first quarter of the twentieth century, new immigrants from South-Africa and Tunisia would join the movement of African migrants to Argentina. Those early African immigrants, like recent immigrants, benefited from the open and generous migration policies implemented by Argentinian governments (although the policies were more intended for Europeans).

Kim Butler (2001) and Caroline Brettell and James Hollifield (2008), among other scholars of migration, have stated the importance of unveiling the identity of the migrants and the rationals of dispersal as one of the frameworks of migration studies. The reasons for the migration of North Africans, South Africans, and Cape Verdeans to Argentina are diverse, personal or collective, known or unknown. As mentioned in the censuses, Moroccans, Algerians, and Egyptians were at the forefront of the African migration to Argentina that started in the 1860 s. Those North African immigrants were multiethnic and comprised of Arabs, Christians, and Jews. North African 
Arab immigrants were part of the vast Arab migration to Argentina that constituted the major Argentine-Arab cultural exchange in the history of the country (Heb 129). ${ }^{17}$ They left their homeland mainly for economic and political reasons. According to Noberto Ivancich, North Africans migrated to Argentina because of the Hispano-Moroccan war of 1859 (Heb 125). Diana Epstein revealed that Moroccan immigrants, mostly composed of Sephardi Jews, landed in Argentina in three waves depending on their objectives and characteristics. The first group arrived between 1870 and 1930 from Northern Morocco, especially from the Spanish region of Tetouan and Tangier (Heb 48). They escaped poverty and sought better economic opportunities. A few numbers of Hispanic Jewish teachers who immigrated to Argentina were recruited from Morocco by the Alliance Israelite Universelle to teach Spanish to the children of the first settlers (Heb 48). The second wave came between 1950 and 1970. These immigrants left mostly for political reasons linked to the independence of Morocco and the creation of the State of Israel (Heb 48). Since 1986, the strengthening of political, commercial, and economic relations between Argentina and Morocco has also intensified the migration of documented and undocumented Moroccans.

The Algerians and Egyptians started migrating to Argentina in the second half of the nineteenth century in search of better economic opportunities. The number of migrants rose a little bit in the twentieth century due to internal and external factors, such as unfavorable economic situations that affected both nations; collateral damage from the French occupation and the war for independence in the case of Algeria; and political and demographic pressure in the case of Egypt, combined with the wars of 1967 and 1973. The small number of Egyptians who migrated before 1974 included primarily professionals. To alleviate the pressure on domestic employment, the government lifted all restrictions on labor migration after 1974 (Zohry 129-149). Moreover, the official trips of presidents Carlos Menem to Morocco in 1996 and Egypt in 1988, as well as Cristina Fernández de Kirchner to Egypt in 2008, have not only solidified the economic ties between the countries but also facilitated the migration of Egyptian professionals and students to Argentina. Below is the estimation of the 2013 Argentina Trade Balance in Thousands of Dollars (INDEC, Comercio exterior 70$){ }^{18}$

\begin{tabular}{|l|c|c|c|}
\hline & EXPORTATION & IMPORTATION & BALANCE \\
\hline Algeria & $1,664,310$ & 10,000 & $1,664,229$ \\
\hline Eqypt & $1,317,458$ & 49,686 & $1,200,914$ \\
\hline Morocco & 516,054 & 511,206 & 466,418 \\
\hline
\end{tabular}

The immigration of North Africans in Argentina in the first decade and half of the twenty-first century is limited and does not seem to significantly increase compared to the immigration of Sub-Saharan Africans.

Like Moroccans, Egyptians, and Algerians, Cape Verdeans arrived in Argentina in the second half of the nineteenth century. They were hired by North Americans as mariners to hunt whales in the Argentinian southern seas (Maffia, "Migration and identity" 169). Another group arrived as "members of board crews, or as stowaways" during the first decade of the twenty-first century (169). The migration intensified in the 1920 s and 30 s when Cape Verde faced one of the worst famines in its history, coupled with the negative impact of the Great Depression. Another important wave of migrants started in the 1940s, during the large famines of 1940-1946 and after the Second World War. Because of their skill as sailors and fishermen, Cape Verdeans settled mostly in port cities such as Rosario, Buenos Aires, San Nicolás, Bahía Blanca, Ensenada, and Dock Sud. The migration flow toward Argentina decreased in favor of European countries such as Portugal, Belgium, Italia, and Holland. In 2006, the journalist Jorge Palomar estimated the population of Cape Verdeans living in Argentina to be between 12,000 and 15,000 (La Nación). Most of them have been naturalized.

Cape Verdean migrants originally came to Argentina with Portuguese passports, since their homeland was still a Portuguese colony (until July 5, 1975). Their disassociation with Africanness and Blackness is manifest in the following report done by the anthropologist Marta Maffia after interviewing Argentinians of Cape Verdean descent in 1998:

Different reasons, not always explicit, were determined through the interviews. On the one hand, there were those whose memory of their place of origin was so traumatic that they preferred to eliminate any element that triggered it. Others denied their African, Black, Cape Verdean origin calling themselves Portuguese, to the point that they refused to be censused for not considering themselves Cape Verdeans. And finally, those who, having acquired better social conditions, did not want any contact with those of lower social positions. ("Migration and identity" 171-172)

The problem with the de-Africanization of Cape Verdeans is also common to other African diasporic communities around the world. The rejection of Africanness in favor of Portugueseness in the specific case of the Cape Verdeans in Argentina is rooted in the history of the archipelago. Under Portuguese rule, Cape Verdeans shied away from their African identity. After decades of colonization and miscegenation, most of them were proud to acculturate and adopt Portuguese values and identity. They were eager to hide or de-Africanize themselves. 
We should bear in mind that 'in Cape Verde, the struggle for making the traits of an African heritage invisible became particular relevant in the so called Barlovento islands ... considered free zones of African ethos ...' (Fernándes 2002, p. 90). As it is clearly expressed by Alejandra, a Cape Verdean descendant: 'First of all, Portuguese colonization was devastating ... that we are different, that we are more intelligent, that we are prettier, more educated, that we have nothing to do with the continental Africans, all this story is believed and repeated by all Cape Verdeans, even by the most ignorant of all (qtd. in Maffia, "Migration and identity"173).

With this Eurocentric mentality and Portuguese nationality, the "old" Cape Verdean immigrants in Argentina did not want to associate with Blacks or other minorities. The desire to isolate themselves from the Black diaspora community and associate with Portuguese and Europeans was not successful in many cases. Marta Maffia revealed that:

The rest of the population did not recognize them (not even today) either as Portuguese or as Argentinean: 'There are no Black people in Argentina' and were even less recognized as Cape Verdeans: they are 'from Brazil', 'Central America', 'Cape Verde?' Where is that? Southern Africa? Ethnic labels and stereotypes activated and became relevant in face-to-face social interactions. (174)

The "African-phobia" of Cape Verdeans would not last forever. The ideological shift occurred after the independence of Cape Verde in 1975 and the visit of President Aristides Pereira to Argentina in 1987. These two events cemented the rapprochement between the island and its diaspora, restoring the link that was once broken. Furthermore, the airline connections between Buenos Aires and Sal, as well as telephone communication, the Internet, and social media have increased interrelations between Cape Verdean natives and descendants, thus creating a fluidity and renewal of cultural interaction and a profound desire to reconnect and share experiences. By the 1990s, the new generation of Argentinians of Cape Verdean descent started to redefine their identity, embrace blackness, and consider themselves "Black Cape Verdeans born in Argentina, considering their culture as Cape Verdean with African influence" (Correa 90-91). Argentinian commercial trade with Cape Verde is minimal, and only relates to exportation that reached 5,041 in thousands of dollars in 2012 and 3,704 in thousands of dollars in 2013 (INDEC, Comercio exterior 70).
2013 Argentina Trade Balance in Thousands of Dollars (INDEC 2014: 70).

\begin{tabular}{|l|c|c|}
\hline & EXPORTATION 2012 & EXPORTATION 2013 \\
\hline Cape Verde & 5,041 & 3,704 \\
\hline
\end{tabular}

Besides the Cape Verdean community, South Africans are also among the early Sub-Saharan immigrants to Argentina. They first arrived between 1902 and 1908 following the 1899-1902 Anglo-Boer War in which they lost wealth, farm and freedom. They came mostly from the Transvaal Province and Orange Free State and settled in Argentinian province of Chubut as farmers and ranchers. According to Mg. Eugenia Arduino, the first wave of eighteen immigrants arrived in 1902 and was directed toward Pico Salamanca, Río Chico and Pampa Pelada where they received 625 hectares of land. A new contingent arrived in 1903, which prompted the creation of a religious community called Nederduitsch Geref Kerk and directed by Pt. Vorster (56-58). This second wave must have had around 240 people since the census of 1914 recorded the population to be 258. A third group came in 1905, and a fourth in 1908. The immigrant population had grown to 800 people in 1908 (58-61). ${ }^{19}$ Some Boers living in Argentina have estimated the number of South Africans living in Argentina in 1909 to be around 3000 people (Davies, "End of an Era"). Many Boers returned to South Africa after the creation of the Union of South Africa in 1910 and mostly after 1924 when the Afrikaner national party rose to power in South Africa. South Africans remaining in Argentina became citizens and created a new identity or a third space that resulted from the fusion of the original culture to the Argentinian one.

The abolition of Apartheid opened a new era in Argentina-South African cooperation. Recent migration of South Africans to Argentina involved mostly students and business professionals from different ethnic-racial backgrounds (White, Black and "Coloured"). The ArgentineSouth African Chamber of Commerce has and continues to enhance/ strengthen the bilateral trade relationship between the two countries. The table below shows the volume of trade with South Africa in 2012 and 2013.

2012-2013 Argentina Trade Balance in Thousands of Dollars (INDEC Comercio exterior 70).

\begin{tabular}{|c|c|c|c|c|c|c|}
\hline \multirow{2}{*}{} & \multicolumn{2}{|c|}{ EXPORTATION } & \multicolumn{2}{c|}{ IMPORTATION } & \multicolumn{2}{c|}{ BALANCE } \\
\cline { 2 - 7 } & 2012 & 2013 & 2012 & 2013 & 2012 & 2013 \\
\hline $\begin{array}{c}\text { South } \\
\text { Africa }\end{array}$ & 1.030 .103 & 733.107 & 238.116 & 242.534 & 791.987 & 490.573 \\
\hline
\end{tabular}


It is also important to underline that the early migration of South Africans to Argentina complicates the European immigration narrative that Argentina celebrates. Contrary to other early African immigrants, the Boers were welcomed to Argentina by the government of President Roca, who gave them lands in the Patagonia region. As white skilled farmers and ranchers, the South Africans fit the profile of the immigrant that the Argentinian authorities was looking to whiten the population and modernize the country. Europe as a geographical location has continuously been viewed as the site where migration to Argentina was encouraged and celebrated. The whitening of the Argentinian population and the modernization of the country are framed as the result of European immigrants. The migration of white South Africans to Argentina proves (symbolically) that the African continent and not only Europe contributed to the whitening of Argentina as well as its agricultural development. If Argentina celebrates her whiteness, the narrative should not only look towards Europe, but also Africa (White South Africa).

In contrast to North Africans, Cape Verdeans, and South Africans, other African immigrants arrived in Argentina in the 1990 s and 2000s. They were mostly undocumented, seeking asylum or refugee status. Those immigrants came from West, Central, East, and Southern Africa. The majority are Senegalese, Sierra Leoneans, Liberians, Nigerians, Ghanaians, Bissau Guineans, Cameroonians, and Ivorians. In order to understand the recent African migration to Argentina, it is imperative to know the internal, external, and international factors that led them to leave their homeland. These factors are mutually inclusive. Contrary to Europe and North America that tightened their immigration policies because of ideological threats of transnational terrorism after September 2011 (and the devastating effects of the Wall Street financial meltdown of 2008 on their economies), Argentina has loosened them over the last two decades (Marcelino and Cerrutti 2012). The openness of immigration laws became even more progressive during the socialist presidencies of both Néstor Kirchner (200307) and Cristina Fernandez de Kirchner (2007-15). The progressive migration Law 25.871 represents an improvement of migrants' human rights. The new law recognizes the fundamental right to migrate, promotes social and labor integrations of immigrants and also guarantees that the undocumented migrants will not be prevented access to fundamental rights. Law 25.871 stipulates in article 3 that any person who requests to be admitted permanently or temporarily to the country, enjoys the right to non-discriminatory criteria and procedures in terms of rights and guarantees established by the National Constitution, international treaties, bilateral agreements and laws. The government has the obligation to implement measures that promote the legalization of foreigners, and should guarantee the right to family reunification of immigrants.
In 2006 , the congress approved and promulgated the Refugee Law 26.165 that recognizes and protects refugees. Moreover, as Pedro Marcelino and Marcela Cerrutti put it: "The principle of non-refoulment is followed in both countries, and Argentina in particular does not practice repatriations (even when they are sometimes ordered)" (120). Article 2 of Law 26.165 precisely prohibits the government to repatriate, sanction or discriminate against immigrants who came into the country illegally. According to Article 8, a refugee can be repatriated only in exceptional cases when he/she is a danger to national security or public order. Even in this case the refugee has the right to use all the administrative and judicial resources to exonerate him/herself. ${ }^{20,21}$ Immigrants are also granted access to health care and education regardless of his/her immigration status. Due to these laws, the weakness of government to control and monitor undocumented migrants and visa overstaying, as well as the flexibility to obtain temporary and provisional resident permits and citizenship, lead Sub-Saharan Africans to migrate to Argentina in the 21st century, mostly illegally, and in large numbers.

Since Argentina's economy itself has declined sharply in the last decade and half, it has become harder to claim refugee status solely on economic ground. The concept of refugee as written in article 4 of Law 26.165 applies mostly to those individuals whose life, security, or freedom has been threatened by generalized violence, foreign aggression, internal conflicts, and massive violation of human rights. It also applies to those persecuted for their social group or political beliefs, race, religion, and nationality. Some undocumented immigrants would rather claim political, religious persecutions, or humanitarian reasons to make their asylum case stronger.

The majority of Sub-Saharan immigrants in Argentina enter the country illegally or as transitory residents, but overstay their visas. They are mainly refugees or asylum seekers who arrive by plane with a tourist visa through Brazil, then cross illegally through the triple border between Paraguay, Brazil, and Argentina. The transit into Argentina is done through smuggling and trafficking networks. ${ }^{22}$ The majority of immigrants are male, and bachelors in their twenties and mid-thirties. Some of them are even teenagers whose age varies between 12 and 17. For example, the first African came to Rosario in 2004 and was a 12 year old boy (Arach, "Los expulsados de la tierra"). ${ }^{23}$ Other immigrants also arrived in Argentina hidden as stowaways (polizones) on container ships, and survived on water and biscuits. ${ }^{24}$ If immigrants cannot stay in containers, they take the extraordinary risk to hide inside the ship's rudder as the Argentinian immigration director Fernando Manzanares explained, "We've seen cases where they arrive hidden inside the rudder of a ship...Imagine what it's like to cross the Atlantic hidden in such a small space, trying to evade the crew" (qtd. in Henao, "African immigrants"). 
Some migrants board the ships with the intention of sailing to North America and the USA specifically. Unfortunately, they end up in Argentina due to possible reroutes, mechanical problems or other "unknown" reasons. That was the experience of Sierra Leonean Ibrahim Abdoul Rahman and Liberian Emmanuel Danso, reported in 2011 by the journalist Luis A Henao: “One night I went to the seaport. I was thinking I was going to Europe. Later I found out I was in Argentina,' said Sierra Leone immigrant Ibrahim Abdoul Rahman, a former child soldier who said he escaped his country's civil war by sneaking into a cargo ship for a 35-day voyage" (quoted in Henao, "African immigrants"). The experience of this immigrant corresponds to what Silvia Costanzi from the Argentinian Catholic Commission for Migration told the daily news La Nación: “Cuando llegan, muchos no saben que vienen acá. '¿Dónde estoy? ¿Qué es Buenos Aires?', preguntan” (qtd in Quiroga, "Africa en Buenos Aires"). This unfortunate circumstance causes trauma to those migrants whose dream and aspiration to reach the wealthy shores of North America are shattered. They find themselves stranded in Argentina.

According to Law 26.165 , those who are seeking refugee or asylum status must apply to the Office of the National Commission for Refugees (CONARE). They receive a temporary certification/provisional residence that allows them to obtain a Labor Identification Code (CUIT/CUIL) and work legally according to the labor guidelines. The provisional residence is valid for 180 days. It can be renewed until the immigrant application is finalized. The petitioner also received basic financial support of the government for six months (at most) as well as psychological and medical aid when needed. Those who finally obtain refugee status receive the temporary residence from the National Direction for Migration (DNM) and the National Identity Document (DNI). They can apply for naturalization within two years of residency if they see fit. If the CONARE rejects an immigrant claim, he/she can appeal the decision before the Minister of Interior. If it is not successful, the petitioner can then request a judicial revision of the decision with the assistance of a lawyer.

It is important to underline that many Sub-Saharan immigrants who came to Argentina illegally (and mainly before 2008) have regularized their migration status either as refugee or were given asylum. As Barbara Hines points out, those who entered the country before 2008 have greatly benefited from the government implementation of Article 17 of Law 25.871 which at first was reserved for citizens from Mercosur, and now included non-Mercosur population:

In June 2004, the government implemented Article 17 of Law 25.871, which mandates that the government establish mechanisms to legalize the status of irregular immigrants, by decreeing a legalization program for non-Mercosur citizens...The decree grants temporary status for two years to anyone residing in the country as of June 30, 2004, and provides for subsequent permanent residence status under Law 25.871. As of 2008, 12,062 applications had been granted.... (Hines 506)

Despite Argentina's pro-immigration laws, the "El Dorado" has been converted for many immigrants into a trap where they face daily unemployment, low paying jobs and poverty. Congolese Celestine Nengumbi Sukama who has lived in Argentina for almost two decades and chairs the Institute for Equality, Diversity, and Integration, argues that "The (government) open arms stop short of giving any form of helping hand once settle in the country...They let you enter. If you can manage to survive, that is Ok" ("African Immigrants"). Nengumbi's remark underlines not only the problem between the laws and their effective implementation, but also loopholes in the laws that can make it harder for undocumented immigrants to receive equal treatment. As Hines suggests:

'Article 5 (Law 25.871) contradictorily requires that "the government guarantee ... equal treatment ... so long as they [foreigners] satisfy the established conditions for their entry and stay [in the country], according to the laws ...' A literal reading of the text of this article could lead to the conclusion that some type of disparate treatment might still be permissible against persons in irregular status... Article 28 also clarifies that citizens of countries with whom Argentina has entered into a specific migration agreement shall enjoy the most favorable treatment, either under the immigration law or the migration agreement.' (490-91)

According to these provisions (Articles 5 and 28), immigrants whose status is not regularized and who do not come from countries that have migration agreements with Argentina might not have equal access to all rights and privileges afforded to citizens. It is even harder for undocumented immigrants who are not allowed to sign leases since the implementation of "Law 25.871 that also prohibits the renting of housing to persons in irregular status and imposes administrative fines for any violation" (496). They are forced to live on the street, share cheap hotel rooms with other immigrants or live in crowded apartments that were rented by documented immigrants.

Besides poverty, immigrants are facing incipient racism and persecution. For being Black and a minority, Sub-Saharan Africans are victims of racism and discrimination that they were not accustomed to in their homeland. The phenomenon of immigration has fostered the othering of foreigners and mostly those coming from third world countries. Even though there are laws against racism and discrimination, they are seldom enforced. Suspicion of theft 
and slurs on the streets are frequent/common signs of discrimination against Blacks. As Nengumbi Sukama states in Reportaje America TV Argentina: "They have called me 'negro de mierda/nigger' thousands of time until today. I filed numerous complains in vain" ("Los argentinos"). Coping and dealing with racial discrimination is a very traumatizing experience for many first-generation Black African immigrants. The National Institute against Discrimination, Xenophobia and Racism (INADI) created in 1995 by Law No 24.515 and under the Ministry of Justice and Human Rights has been instrumental in combating racism, but more work still needs to be done.

African immigrants from North, South, West, Central, and East Africa, documented or undocumented, are the new faces of the African diaspora in Argentina. As diverse as they can be in terms of ethno-racial, religious beliefs, and nationational of origin, they are challenged by their new environment and the Argentinian socio-cultural normativity. Northern Africans, despite their limited number, are also facing discrimination like Sub-Saharan Africans and other immigrants from Latin-America. Northern Africans are mostly Afro-Asiatic, Nilo-Saharan, Semitic, Berber. Even though some of them can pass for White on the street, they are discriminated against because of their immigration status, ethnicity, and religion, labeled "Immigrant-African Origin-Arabic-Muslim". Not all Northern Africans can pass for White; there are some of darker phenotype who easily fit within the Black communities. The same goes with South African immigrants. Contrary to the early immigrants who were all White and Afrikaners, today immigrants are Black, "Coloured", and non-Boers White.

In order to survive as an African diaspora community, North Africans, Sub-Saharans, as well as Black and "Coloured" South Africans, need to foster a more inclusive partnership and relationship among themselves, as well as create more mixed associations that are not just ethno-racially, religious, or nationality based. The resurgence of the spirit of Pan-Africanism, at least in its ultimate objective of unifying and consolidating the African diaspora, is essential to achieve unity, prosperity, and security in a society that is becoming more xenophobic. North African, Sub-Saharan, and South African (Black, "Coloured") immigrants should embrace and be proud of their Africanness, instead of disavowing or excluding themselves from it. By embracing and celebrating their African origin, those African Immigrants as a whole will contribute more to the (re) Africanization of the Argentinian society, as well as encourage the ideals of multiculturalism that are voiced by the authorities and a new image of the country. The Africanization of the Argentinian society is not a new phenomenon since Argentina has a rich history of African influence through the socio-cultural, economic, and political contributions of slaves and AfroArgentinians. Even though these contributions have been silenced for centuries in the national consciousness, they have resurfaced in national discourses in the past decade and a half.

The increased number of recent African immigrants will have the potential of reshaping the socio-cultural landscape of Argentina as they did in European countries, especially in France, in the last 50 years. The Africanization of Argentinian society is being noticed in music, sport, academia, and gastronomy. For example, among the renowned Argentinians of Cape Verdeans descent who have impacted the culture are movie actors Luis Medina Castro (1928-1995) and Diego Alonso Gómez (1973-), singer and composer Juan Carlos Cobos (1928-1999), football player José Manuel Ramos Delgado (1935-2010), Antonio Custodio Méndes, and intellectual/activists Miriam Gómes and María Fernanda Santos, among others. In 2005, Abdulaye Badiane founded the music and dance school Dara Chosan, and later, Cheikh Gueye founded the school Daaradji Gaynde Djembe. These schools promote Senegalese culture, and have attracted and taught many Argentinians. Furthermore, physical spaces are also testament of the African influence on Argentinian diversity. For example, the "cantero central Africa" (African median strip) is located on Av. San Isidoro Labrador and was inaugurated in 1988. Some arenas and streets in the province of Buenos Aires are named after Cape Verde. La Plaza República de Cabo Verde is located in the Triángulo de Bernal. Cape Verdean street names are found in Dock Sud and Ensenada. Besides dance and music, gastronomy is also a marker of African identity in Argentina. For example, Cape Verdean dishes like "cachupa" (in its diverse form capucha rica, pobre, frita, refogada o guisada), "Canja de galinha", and "Jagacida" are making their entrance in the Argentinian culinary industry.

Even though these Africans cultural influences are small in scale, they will grow with time as the seed is already planted. Furthermore, the creation of African associations, such as the Casa de Africa de la Argentina founded in 1995 by Irene Ortiz, help promote cultural exchange between Africa and Latin America. The Asociación Civil África y su Diáspora founded in 1999 and the Consejo Nacional de Organizaciones Afro de la Argentina (CONAFRO) created in 2010 have spearheaded cultural and political activities aimed at making the African diaspora more visible in Argentina. These movements participated in Africa Week in 2007, renamed African Diaspora Week in 2008, and organized by the Movimiento de la Diáspora Africana. The cultural and political practices of these associations are having some impact on the visibility and recognition of African subjects in the socio-political arena. This activism has caught the attention of the INADI (National Institute against Discrimination, Xenophobia and Racism) since 2006. In July 2007, INADI organized a month-long series of cultural activities to celebrate the first Argentinian Congress about people of African descent. One month later, the Institute organized a seminar on Africa and its 
diaspora. In 2008 and 2009, they promoted awareness sessions entitled "Argentine is also Afro", where Africa and African diaspora cultural practices were presented. In July 2010, the autonomous city of Buenos Aires created the EPIIA (Space of Promotion, Integration, and Exchange with Africa). African organizations are not only incubators and promotors of African cultural practices, they also infused those practices in the society. For African immigrants, they constitute a homestead, physical and symbolic spaces of affirmation and resistance. As bell hooks articulates it, they constitute "homespaces", or spaces for identities and communities of resistance in white supremacist societies (42). Beyond resistance against racism and affirmation of ethnic identities/ affiliations for its members, ethnic associations also provide mutual aid and the first step of integration into the web of the migration process.
This analysis is ultimately an invitation for more in-depth studies on recent African immigrants in Argentina, the reasons for leaving their homelands, how they arrived in Argentina, their problems and success (his)stor(ies) as they embark on the transformation of the Argentinian society. Furthermore, the particular examples of Northern African (Afro-Asiatic, Nilo-Saharan, Semitic, Berber) and Southern African (Black, "Coloured", White) immigrants highlight the need to rethink the way we discuss the African diaspora in the twenty-first century, so as to foster a larger dialogue in such a way to avoid falling into a false paradigm that equates Pan-Africanism solely with Pan-Negroism.

\section{NOTES}

1. I would like to take this opportunity to thank Prof. Rebecca Hankins (TAMU) for her insightful comments on the paper.

2. The manifestation of the historical amnesia of Blackness is widespread among Argentinians as reporter Rosario Gabino stated in BBC Mundo (2007): “'En Argentina no hay negros'. Esta frase está instalada en el imaginario popular." [“There is no Black in Argentina'. This sentence is engrained in popular imaginary." (“¿Hay negros en Argentina?']

3. George Reid Andrews. The Afro-Argentines of Buenos Aires, 1800-1900 (1980); Dina Picotti (comp). El negro en la Argentina: presencia y negación (2001); Marvin Lewis. Afro-Argentine Discourse: Another Dimension of the Black Diaspora (1996); Alejandro Solomianski. Identidades Secretas: La Negritud Argentina (2003); Alejandro Frigerio, and Eva Lamborghini. "Los Afroargentinos: Formas de comunalización, creación de identidades colectivas y resistencia cultural y política" (2011); Paola Monkevicius, and Marta Maffia. "Memory and ethnic leadership among Afro-descendants and Africans in Argentina" (2014); Alex Borucki. From Shipmates to Soldiers: Emerging Black Identities in the Rio de la Plata (2015); and Erika Edwards. "The Making of a White Nation: The Disappearance of the Black Population in Argentina" (2018).

4. Because of the effort of activists and the Black communities, the government of Argentina has declared
November 8th as "Day of Afro-Argentine and Afro Culture."

5. The African immigrants I spoke with couldn't let me use their names or nicknames. In this paper, I relied mostly on interviews done by journalists.

6. This study doesn't intend to discuss migration theories and methodologies, but uses some of the framing questions and ideas/framework stated by Kim Butler, Hasia Diner, Caroline Brettell and James Hollifield to better understand African migration to Argentina.

7. Primer censo de la República Argentina (1869). The census was conducted under the supervision of Diego G de la Fuente and published in Buenos Aires in 1872.

8. Besides "African" as a racial category in the census of 1895, other categories included the Asians (414 members), the Scandinavians (3085), Slavs (15170), Anglo-Saxons (23200), Germanic (47615) and Latin $(3,800,537)$ (Fuente XLV). The Commission didn't specify the difference between Germanic, Scandinavians and Anglo-Saxons.

9. The Commission reported that the Blacks "no pueden propagarse puras en proporción bastante para perpetuarse, cuando los varones están en semejante minoría, puesto que las mujeres por su contacto con el elemento blanco, van produciendo cada vez mayor número de mestizos, mientras que disminuyen el de los 
negros puros" [they can not increase pure enough to last long, when the number of males are small as well, since females are giving birth to a growing number of Mestizos because of their relation with Whites, while the number of pure Blacks are diminishing] (Fuente XLVIII).

10. North Africans are not all "White", they are ethno-racially and religiously diverse (Afro-Asiatic, Nilo-Saharan, Semitic, Berber, Arabs, Jews, Muslim, Christian etc.). Those who migrated to Argentina could have been people who easily passed for White.

11. In the category "Raza latina" (Latin race), the Commission made a distinction between Argentines, Spanish America and Latin of other languages. The latter included Italians, Spaniards, French, Portuguese and other European nations.

12. Alberto Martínez, Alberto. Tercer Censo Nacional. Buenos Aires. Buenos Aires: Talleres Gráficos de L.J Rosso y Cía, 1916.

13. The total number of Africans was 2827 , among which 1471 were males and 1356 were females (Dirección Nacional de Estadística y Censos 14).

14. The total number of Africans was 1,883; among which 1,083 were males and 855 were females (INDEC, Censo Nacional de Población Y Viviendas 2001).

15. Marta Maffia ("La migración subsahariana" 71).

16. The majority came from Senegal (71), Sierra Leona (71), Liberia (67), Nigeria (54), Ghana (26), Bissau Guinea (24), Ivory Coast (22), Mali (16), and Angola (15). The rest of the refugees arrived from Congo (10), Zaire (7), Burundi (6), Cameroon (6), Ethiopia (6), Guinea Conakry (5), Somali (5), Soudan (4), South Africa (3), Central Africa (2), Eritrea (2), Mauritania (2), Zimbabwe (2), Kenya (1), Rwanda (1), Chad (1) and Togo (1). According to the DNM database from 2004-2010, Africans with permanent settling totaled 231 including immigrants from Senegal(69), Nigeria (37), South Africa (28), Cameroon(21), Ghana(17), Sierra Leon (15), Angola (11), Burkinabe (9), Kenya (7), Ivory Coast (7), Mali (6) and Congo(4) (Maffia, "La migración subsahariana" 73). Those with temporary settling were 292 divided among Senegal (81), Nigeria (53), Ghana (40), Sierra Leon(33), South Africa (30), Angola (28) and Cameroon (27). These data were compiled by Marta Maffia ("La migración subsahariana" 72).
17. Gustavo Dalmazzo stated that Arab immigrants started to arrive in Argentina in 1860 (20).

18. INDEC. Comercio exterior argentino 2013. Buenos Aires: Centro Estadístico de Servicio, 2014.

19. Richard Davies also revealed that "up to 800 Boer families trekked by ship to this lonely spot on Argentina's east coast, about $1500 \mathrm{~km}$ north of Tierra del Fuego" (Mail\&Guardian).

20. If the expulsion of the refugee is definite, the government must give him/her enough time to legalize his entry into a third country that will guarantee his right to life, liberty and security (Law 26.165 article 8).

21. However, Article 29 of Law 25.871 prevents the entry into Argentina or the residency to people who have altered or presented false documentation; those jailed abroad or in the country for human and arm trafficking, money laundry; those who have committed terrorism, genocide or crime against humanity among other crimes.

22. The visa to come to Argentina from Africa is obtained through Argentina embassies only in Algeria, Angola, Egypt, Kenya, Nigeria, Tunisia and South Africa. Many Senegalese immigrants obtain tourist visa from the Brazilian embassy, and once in Brazil some decide to stay indefinitely and other migrate to Argentina.

23. In December 2008, the journalist Evelyn Arach also reported in the newspaper Rosario 12 that the ship Centaurus arrived in the port of Timbués with 3 Nigerian teenagers of 15 and 16 years of age. For the past three months, three ships have docked in Rosario's port with 2 teenagers on board. These teenagers are hosted by reverend Tomás Santidrián who before has received 13 years old John Opara and 15 years old John Friday from Nigeria. In 2007, 40 undocumented Africans arrived in Rosario and in 2008 the number grew to 70 ("Los expulsados ").

24. Anne Herrberg in "African refugees turn to Latin America over Europe" (2011) reports on the case of the Ivorian Koaku Bu Date Rodrigue who came to Argentina in 2009: " 'It's cold," says one of the vendors, rubbing his hands. The 25-year-old came to Argentina two years ago. 'My country is in a civil war. I was forced to fight in a rebels' group,' ... 'One morning I managed to escape. I made my way to San Pedro port and hid in the container room of a ship.' Koaku doesn't remember just how long he had to hide for. When the ship stopped moving he was in Argentina." (Deutsche Welle). 


\section{WORKS CITED}

"African Immigrants Turn to Argentina for Opportunity." YouTube, uploaded by Celestin Nengumbi. March 1, 2011, https://www.youtube.com/watch?v=zEzl4mK3 $\mathrm{V}_{5} \mathrm{c}$ Accessed 15 January 2019.

Andrews, G. The Afro-Argentines of Buenos Aires, 1800-1900. Wisconsin UP. 1980.

Arach, Evelyn. "Los expulsados de la tierra africana." Rosario/12, 29 December 2008, http://www.pagina12. com.ar/diario/suplementos/rosario/9-16645-2008-12-29. html Accessed 28 january 2019.

Arduino, E. "Reterritorialización de identidades africanas de fe reformada en la Argentina." Identidades afroasiáticas translocalizadas. Intercambios y resignificación sociocultural. Ed. E. Arduino. Mnemosyne, 2014, pp. 50-65.

Aydin, C. "Africa." Transnational History from the Mid-19th Century to the Present Day. Eds. A. Iriye and P. Saunier. Palgrave Macmillan, 2009, pp. 15-18.

Azevedo, M. Africana Studies: A Survey of Africa and the African Diaspora. Carolina Academic Press, 2005.

Borucki, A. From Shipmates to Soldiers: Emerging Black Identities in the Río de la Plata. New Mexico UP, 2015.

Brettell, Caroline and James Hollifield. "Introduction" Migration Theory: talking across Disciplines.” Eds. Caroline Brettell and James Hollifield. Routledge, 2008, pp 1-29.

Butler, K. "Defining Diaspora, Refining a Discourse." Diaspora: A Journal of Transnational Studies, vol. 10, no. 2, 2001, pp. 189-219.

Camino, A. "Africanos en Argentina." Periodismohumano, 29 March 2010, http://periodismohumano.com/migracion/ inmigrantes-argentina.html. Accessed 5 September 2017.

Correa, N. "Afroargentinos y caboverdeanos. Las luchas identitarias contra la invisibilidad de la negritud en la Argentina." MA Thesis, Universidad Nacional de Misiones, 2000.

Dalmazzo, G. and Héctor F. "Los Credos de los Turcos.” Todo es Historia, no. 412, 2001, pp. 18-23.

Davies, R. "End of an Era for Argentina's Afrikaners." Mail\&Guardian, 1 December 2009, http://mg.co.za/article/2009-12-01-end-of-an-era-for-argentinas-afrikaners. Accessed 20 September 2017.

De la Fuente, D. Segundo Censo de la República Argentina 1895. Taller Tipográfico de la Penitenciaria Nacional. 1898.

---. Primer Censo de la República Argentina (1869). Imprenta del Porvenir, 1872.

Diner, Hasia. "History and the Study of Immigration: Narratives of the Particular." Migration Theory: Talking across Disciplines. Eds. Caroline Brettell and James Hollifield. Routledge, 2008, pp. 31-49.

Dirección Nacional del Servicio Estadístico. IV Censo General de la Nación: Población 1947. Ministerio de Asuntos Técnicos, 1955.
Dirección Nacional de Estadística y Censos. Censo nacional de población 1960. Secretaría de Estado de Hacienda, 1963.

Edwards, Erika. (2018), 'The Making of a White Nation: The Disappearance of the Black Population in Argentina', History Compass, vol.16, no. 7, 4 July 2018, https://doi. org/10.1111/hic3.12456. Accessed 21 January 2019.

Epstein, D. "Los judíos marroquies en Buenos Aires." Temas de Patrimonio Cultura 2: Buenos Aires Sefardí. Comp. Carlos Szwarcer. Comisión para la Preservación del Patrimonio Cultural de la Ciudad Autónoma de Buenos Aires, 2008, pp. 47-66.

Frigerio, A. "De la 'desaparición' de los negros a la 'reaparición' de los afrodescendientes: Comprendiendo las políticas de las identidades negras, las clasificaciones raciales y de su estudio en Argentina." Los estudios afroamericanos y africanos en América Latina: herencia, presencia y visiones del otro. Ed. A. Frigerio. CLACSO, CEA-UNC, 2008, pp.117-144.

Frigerio, A and Lamborghini E. "Los Afroargentinos: Formas de comunalización, creación de identidades colectivas y resistencia cultural y política." Aportes para el desarrollo humano en Argentina. Ed. PNUD. PNUD, 2011, pp. 1-51.

Gabino, Rosario. “¿Hay negros en Argentina?” BBC Mundo, 16 March 2007, http://news.bbc.co.uk/hi/spanish/ specials/2007/esclavitud/newsid_6455000/6455537.stm. Accessed 30 January 2019.

Heb, S. El Intercambio Comercial, Cultural y tecnologico entre Argentina y Túnez. Un desafio par alas relaciones Sur-Sur. Diplomica Verlag GmbH, 2008.

Henao, L. "African immigrants drift toward Latin America." Reuter, 3 October 2011, http://blogs.reuters.com/luis-a-henao/2011/10/03/african-immigrants-drift-toward-latin-america. Accessed 3 July 2017.

Herrberg, A. (2011), 'African refugees turn to Latin America over Europe', DW Deutsche Welle 20 June, http://www. dw.de/african-refugees-turn-to-latin-america-over-europe/a-15174828. Accessed 5 May 2016.

Hines, Barbara. "The Right to Migrate as a Human Right: The Current Argentine Immigration Law." Cornell International Law Journal, no. 43, 2010, pp. 471-511.

Hooks, b. Yearning: Race, Gender, and Cultural Politics. South End, 1990. Instituto Nacional de Estadística y Censos (INDEC). Comercio exterior argentino 2013. Centro Estadístico de Servicio, 2014.

---.Censo Nacional de Población, Hogares y Viviendas 2010. Censo del Bicentenario. INDEC, 2012.

---.Censo Nacional de Población Y Viviendas 2001. INDEC, 2004.

Ivancich, $\mathrm{N}$. El estado argentino ante la inmigracion. Ministerio del Interior. Dirección Nacional de Migraciones, 1998. 
Lawo-Sukam, A. "Blackness In Argentina: A Quest for Legitimacy." PALARA: The Afro-Latin American Research Journal, no.19, 2015, pp. 92-118.

Maffia, M. "La migración subsahariana hacia Argentina: Desde los Caboverdianos hasta los nuevos migrantes del siglo XXI." Aportes para el desarrollo humano en Argentina. Eds. R. Mercado and G.Catterberg. PNUD, 2011, pp. 52-89.

---."Migration and Identity of Cape Verdeans and their Descendants in Argentina." African and Black Diaspora: An International Journal, vol.3, no.2, 2010, pp.169-180.

Marcelino, P. and Cerrutti, M. "Recent African Immigration to South America: The Cases of Argentina and Brazil in the Region Context." Development, institutional and policy aspects of international migration between Africa, Europe and Latin America and the Caribbean. Eds. J. Martínez Pizarro and L. Reboiras Finardi. Economic Commission for Latin America and the Caribbean ECLAC, 2012, pp. 107-145.

Martínez, Alberto B., Tercer Censo Nacional. Buenos Aires 1914. Talleres Gráficos de L.J Rosso y Cía, 1916.

Monkevicius, P and Maffia M. "Memoria y límites étnicos entre los caboverdeanos de Argentina." Boletín de Antropología, vol. 24, no. 41, 2010, pp. 115-133.

---."Memory and ethnic leadership among Afro-descendants and Africans in Argentina." African and Black Diaspora: An International Journal, vol.7, no. 2, 2014, pp. 188-198.

Palomar, J. "Caboverdianos: vientos de cambio." Revista del Diario La Nación, 3 December 2006, http://www. lanacion.com.ar/862751-caboverdianos-vientos-de-cambio. Accessed 4 October 2017.

Quiroga, J. “Africa en Buenos Aires.” La Nación, 25 April 2009, http://www.lanacion.com.ar/1121658-africa-en-buenos-aires. Accessed 4 April. 2016.

Reportaje America TV Argentina. "Afroargentinos la nueva inmigración africana en Argentina.” YouTube, uploaded by Nengumbi Sukama, 31 January, 2011, https://www. youtube.com/watch?v=p8M3I6pyOos. Accessed 16 December 2018.

Zohry, A. "The Place of Egypt in the Regional Migration System as a Receiving Country." Revue Européenne des Migrations Internationales, vol.19, no.3, 2003, p. 1. 